\title{
Communities of Absence: Emotions, Time, and Buddhism in the Creation of Belonging
}

\author{
Erica Baffelli | ORCID: 0000-0003-3236-8814 \\ Department of Modern Languages and Cultures, The University \\ of Manchester, Manchester, UK \\ erica.baffelli@manchester.ac.uk \\ Frederik Schröer | ORCID: 0000-0002-2106-7816 \\ Center for the History of Emotions, Max Planck Institute for Human \\ Development, Berlin, Germany \\ schroeer@mpib-berlin.mpg.de
}

\begin{abstract}
This article argues that belonging can be characterized by absence. It explores this as experienced in two different geographical and historical contexts by two groups of actors: members of the early Tibetan diaspora in India (1959-1979) and former members of a religious group (Aum Shinrikyō) in Japan. The absence we conceptualize is double: it is not solely a spatial absence, but also a temporal absence in terms of the irreversibility of time. It is felt and articulated through emotions that play decisive roles in the constitution and sustaining of these communities. These communities as feeling communities are characterized by absence, but absence is simultaneously what makes them a community. This simultaneity allows our actors to create complex temporal frameworks by relating to reimagined pasts, different presents, and potential futures. Therefore, the article contributes to discussions of belonging by retheorizing the relationship between absence, emotions, and time.
\end{abstract}

\section{Keywords}

absence - time - emotions - community - belonging - Aum Shinrikyō - Tibetan diaspora 
... advancement towards enlightenment is gained only through pain, not through pleasure.

RINCHEN DOLMA Taring, Daughter of Tibet

This article argues that belonging can be characterized by absence. Drawing on examples from our respective work on the early Tibetan diasporic community and on members of a minority religious group in Japan, we show that in certain conditions, communities exist precisely because absence shapes them; absence can therefore be a root condition of belonging. ${ }^{1}$ Such absence is felt not only through feelings such as desire or loss, missing or longing; it is not just an absence of a presence, as in an inaccessible homeland or the inability to perform religious rituals and practices. Rather the very presence of absence the shared experience of being in an overwhelming situation of absence - can itself produce belonging.

Like all of the contributions to this special issue, the perspective guiding us in our actor-centered reflection on belonging is that afforded by a "new" or "wider" aesthetics (Meyer 2009; Baffelli et al. 2021), which takes aesthetics as aisthesis, that is, the entire process of (human) sense perception. ${ }^{2}$ We come to this topic from different disciplinary and methodological backgrounds. Erica Baffelli works on new religious communities in Japan through interviews and the analysis of media practices, while Frederik Schröer is a historian of the early Tibetan diaspora in India, tracing its central concepts and emotions in discourse and practice through archival and public sources. This article analyzes absence and belonging in these two contrasting but resonant sites of inquiry. While our goal is not comparison per se, bringing our work into dialogue allows us to formulate systematic theoretical observations that can be productive beyond our case studies. In the specific geographical and historical contexts that we have researched, we have observed different dynamics of

1 While the Tibetan community in exile conforms neatly to the classical criteria of diasporas as listed in Safran 1991, the terms diaspora and diasporic are here used not as prescriptive but descriptive, to describe a "condition of subjectivity" (Cho 2007: 14). On the larger debate on the analytical concept of diaspora, see also Tölölyan 2007.

2 This is also the approach more generally taken by scholars working on the aesthetics of religion. See, for example, Grieser and Johnston 2017; Johannsen, Kirsch, and Kreinath 2020. 
community formation. Both of the communities that we study also draw heavily on Buddhist epistemologies. As we will show, Buddhist semantics infuse our actors' key emotional concepts, such as suffering, and supply ways of relating between different times through ideas such as karma and reincarnation. This shapes the ways in which our actors feel the presence of absence, and how they mediate it across time. The aim of our article is to jointly develop theoretical reflections on belonging that might be applicable to other cases, as well as those that speak more directly to the specific topic of this issue: Buddhist belonging.

The examples that we draw on are based on Schröer's work on the early Tibetan diaspora in India, particularly in the 196os and 1970s, and Baffelli's work on a group of former members of Aum Shinrikyō (hereafter Aum). Aum is a religious organization established in Japan in 1984. It rose to infamy when some of its members perpetrated a sarin gas attack in the Tokyo subway in 1995, killing fourteen people and injuring thousands in what was one of the defining events of the Heisei era (1989-2019) (Baffelli and Reader 2018). Aum started as a small yoga group led by Asahara Shōkō (b. Matsumoto Chizuo, 1955-2018), but by 1995 had grown into a larger organization with about a thousand of its members living in communes as renunciates (shukkesha). Aum's teachings were influenced by Buddhism, extreme ascetic practices, and apocalyptic thought. ${ }^{3}$ After the sarin gas attack, several members were arrested and accused of atrocious crimes such as murder. In July 2018 thirteen of them, including the leader Asahara, were executed (Baffelli and Reader 2018). Membership sharply decreased following the arrests and by April 1998 only five hundred members remained in the communes. Some renunciates felt unable to remain in the organization but were also unable to completely reject the teachings after they had left. The ascetic practices and emotional bonds that had characterized their life in Aum could not be reproduced outside, but these members continued to feel different from "ordinary" people in mainstream society. These feelings created a new sense of belonging.

Tibetan refugees first arrived in South Asia in large numbers following the failed uprising against Chinese rule in Lhasa in March 1959. They strove to form and preserve a coherent community in exile under the leadership of the Fourteenth Dalai Lama, who together with his government-in-exile embodied the Tibetan political concept of the "union of the religious and the political" (Brox 2016: 186-191). Faced with the fear of "scattering and being absorbed like water in sand" (Dalai Lama XIV 1984), Tibetan refugees resisted assimilation

3 For a detailed history of Aum Shinrikyō and its teachings, see: Shimazono 1997; Reader 200o; Inoue and Shūkyō jōhō risāchi sentā 2011, 2015. 
into their new host societies (McGranahan 2018). Central to the emergent diasporic identity was a shared repertoire of emotions and practices that negotiated between exile and homeland, inflected by the religious semantics and authority of figures such as the Dalai Lama.

We conceptualize these groups as "feeling communities," which emphasizes that belonging and communities are constituted by shared emotions and emotional practices. As Margrit Pernau has argued, feelings - contested, controversial, and marked by power - "are at the basis of the creation of communities" (Pernau 2017: 9). ${ }^{4}$ As an analytical concept, "feeling communities" unites two coconstitutive aspects: as much as emotions are formative of communities they are formed by communities through discourse and practice. The concept therefore refers specifically to communities that share an emotional "grammar," rather than to any collectivity whose members share strong feelings for or against something or for themselves. ${ }^{5} \mathrm{~A}$ feeling community, and thus belonging, comes about through reciprocal operations of concepts and practices that constitute both feeling (something) together and feeling (as) together.

We argue that the feeling communities created by former Aum members and Tibetan refugees are, more specifically, what we define as "communities of absence": communities in which members belong through shared feelings of absence. As we will show, members not only share feelings about absent spaces, for example a homeland or a commune; they also share ways of emotionally connecting to and relating between imagined pasts, uncertain futures, and radically different presents. In other words, their emotional grammar is not only tied to the aisthesis of their communities' spatial configurations; their shared emotions are also strongly temporalized. This relationship between time(s) and emotions is, we argue, central to belonging.

This article proceeds in three major steps, taking inspiration from the metaphors of movement through which our actors often talked about absence in

4 We follow the introduction to this special issue in not overly complicating the analytical differentiation between the English terms "emotion" and "feeling" (Baffelli et al. 2021). That said, earlier seminal research into the role of emotions in communities (Reddy 2001), or "emotional communities" (Rosenwein 2006), focused on the culturally normative semantics encoded into emotions within stable social groups, while recent scholarship is increasingly turning to the concept of feelings to include both the learned and historically contingent cultural as well as the felt (or affective) bodily domains in dynamic communities (Gammerl, Hutta, and Scheer 2017: 88; Boddice 2019: 13-14).

5 We use the term "emotional grammar" (Gammerl, Hutta, and Scheer 2017) to refer to socially shared sets of rules and conventions governing the expression, and by extension experience, of emotions within communities. The term "emotional repertoire" (Poser et al. 2019), while related, describes a set of "core" emotions, or their specific interpretations, central to a given feeling community. 
their narratives of leaving and arriving, escaping and hiding, living through, and sometimes moving out or on. We start with "Moving into Absence," offering initial reflections on how the presence of absence can come to be experienced. In both of our examples, absence is the result of traumatic events. Under such conditions, as we will show, belonging very often becomes characterized by suffering, anxiety, loss, and confusion, while belonging before the traumatic interruption or events is remembered by many of our actors in association with beauty, happiness, lightness, and fulfillment. In "Living in Absence," we reflect on the condition of living in the presence of absence and the role this can play in the creation of belonging and the formation of feeling communities. Since this section includes our main theoretical reflections, it is longer than the others. It will explore how and why certain feeling communities can be analyzed as "communities of absence," and what that entails for the analysis of their emotions and practices. Further, this section will show how the emotions of a feeling community are often temporalized in relation to multiple times. In our final section, "Moving Out of Absence," we explore perspectives on the end of absence: if and how communities can imagine futures without absence and how to reach them.

Throughout the article, we point to the religious semantics of emotions, such as suffering, that are central to our actors' belonging, as well as to how Buddhist epistemologies and notions of time inflect absence for them. Our approach to what constitutes an emotion is to follow the emic concepts of our actors. This means attending to the specific cultural semantics that govern how a given emotion is experienced and expressed (Pernau and Rajamani 2016). Suffering is at the very core of all Buddhist epistemologies. The central tenets of the Four Noble Truths, shared across all schools of Buddhism, establish suffering both ontologically (suffering is an endemic condition of Samsara, the cyclical being in the world) and eschatologically (only Buddhism is the path that leads to the ultimate cessation of suffering, in Nirvana) (Harvey 2013). Time, in Buddhism, is not seen as a linear progression but as a relation that is often cyclical and recursive. The connections of karmic cause and effect, as touched upon by Elizabeth Williams-Oerberg (2021), can relate individuals and objects across time, entangled through the idea of "dependent origination." Likewise, as Dominique Townsend (2021) explores, the Tibetan "Treasure tradition" is

6 Sanskrit pratītyasamutpāda, literally "origination (samutpāda) by dependence (pratītya)," refers first to the doctrine of the "twelve links of causation" by which ignorance (avidyā) leads to birth, death, and rebirth through the chains of causality effected by karma; and second, in a more general interpretation favored by some schools of Buddhism, to the interdependence of all things, their parts, and their origination. On dependent origination, see: Harvey 2013; Buswell and Lopez 2014. 
premised on the idea that teachers and teachings can reach through time to manifest effects in a different present. As the following sections will further explore, such religious semantics and temporal relations structure the emotional repertoires we observe as generative of belonging in the communities living under the conditions of absence that we describe.

\section{1 \\ Moving into Absence}

The formation of "communities of absence" can start with a distinct moment or event that creates a separation between what was there before and a new, radically different, condition characterized by absence. In the case of the Tibetan diaspora, the passage into absence was the result of a community's physical displacement. After the failed uprising in Lhasa in March 1959, Tibetan refugees were rebuilding social and political structures while facing the hardships of arriving in foreign lands of exile, struggling for bare subsistence in dangerous Himalayan road construction sites or in the jungles of the first agricultural settlements (Information Office 1981). All members of this first generation of the Tibetan diaspora had, albeit differing, experiences and memories of before and of the move into absence - of oppression, uprising, and escape. The traumatic suffering of material and emotional loss during the refugees' arduous and often fatal escapes across the Himalaya cast a long shadow over the community in exile, though its impact remained socially uneven (Methfessel 1997).

In the case of former members of Aum, the move into absence can be traced back to a very specific moment - March 20, 1995 - when five members entered five lines of the Tokyo subway during the morning rush hour and spread sarin gas. In the weeks and months following the attack, the police raided Aum facilities and arrested hundreds of members, including the leader, Asahara. When the other violent crimes that had been committed by members also started to be publicly exposed, many followers left Aum. Among them was a group of renunciates who felt that they could not continue to be part of the organization but still considered Aum teachings and practice to be valuable and significant. ${ }^{7}$ In the words of one such member - Ueda Naoko, who had joined Aum in its early years - they had felt that "everything was falling apart." Their way of

7 This group does not represent all former members. Some returned to their previous lives and tried to be as discreet as possible, others joined the ex-members' mutual support group Canary Society (Kanariya no kai), while others remained in Aum, renamed Aleph in 1999 (Baffelli 2018, 2020). On Aleph, see also Maekawa 2001.

8 Names have been changed to maintain confidentiality. Interviews and conversations with former members were conducted by Baffelli between September and December 2016 and 
life, daily rituals and practices, which had made sense inside Aum, collapsed and they had to come to terms with absence. They had lost the place where they used to live and practice. They no longer had daily contact with other members and their leaders. Moreover, they became aware that the violence perpetrated by other Aum members, including their leader, made it impossible for them to go back to that way of life (Baffelli, forthcoming).

The absences that former Aum members and Tibetan refugees moved into were, in both cases, double absences of inaccessibility and irreversibility, of space and time. ${ }^{9}$ For the majority of the Tibetan refugees, their diasporic identities were - and often remain - largely defined in relation to the absent homeland. The homeland remained inaccessible from the spaces of exile, particularly during the first two decades of exile (after 1978, Chinese policy reforms allowed a very small number of Tibetan refugees to visit Tibet). But Tibet was also felt as temporally absent from the diaspora through its commemoration of the "free Tibet" of the past, its conception of the (diasporic) present as radically different to that of Tibet, and its vision of a better Tibetan future as one that only Tibetans in exile were free enough to work toward. Similarly, absence was double for some former followers of Aum. It was (and is) spatial; former renunciates stopped living together after 1995 and no longer shared a physical space for their practice. But it also became temporal, since their past lives inside Aum could not be replicated in the present, let alone be imagined in the future.

As we will show, this double absence characterizing belonging for our actors was felt and articulated through emotions and feelings such as suffering and pain. Such emotions played decisive roles not only in how Tibetan refugees and former Aum members made sense of their new conditions of absence, but also in the constitution and sustaining of community. They are expressed in narratives created by community members. While these narratives were publicly expressed and even published by some Tibetan refugees as we will examine below, those of former Aum members emerged in interviews and personal blogs.

Aum, according to Hirano Akiko - a former member who left her job and her husband to join the group and become a renunciate - became an "illusion" after 1995. Some members felt that they could not continue their communal

January 2020. Although the blogs discussed in this article are in the public domain, they contain sensitive materials. Therefore, to protect the identities of the authors and other people mentioned in the blogs the URLs are not included.

9 Not to be confused with the concept of "double absence" used by Sayad Abdelmalek (1999), which refers to the legal and experiential unbelonging of second-generation Algerian immigrants in France, classified as foreign in both countries. 
life and had to find a way to carry on living outside the Aum community. For Hirano and others like her, this involved accepting that the group was responsible for the violence and admitting that Aum was not what they had thought (or made themselves believe) that it was. Many started asking themselves who Asahara really was. One showed Baffelli comments that another ex-member (using a pseudonym) had posted on Amazon under an Aum publication. She said that after the sarin gas attack she had very similar feelings to those expressed in the following paragraph:

After returning to secular life, it was still ok when I was focusing on work to forget Aum.... I started looking into the affair myself and when I tried to understand inside me what Aum was, I couldn't bear the pain.... After I had left the organization and I was thinking about the incident I could not stop thinking all day long about what on earth Asahara, Matsumoto Chizuo was.

MATSU, comments left on May 1, 2019

At the same time, their emotional connections to Aum and its practices still framed how they conceived of the "outside society." According to their accounts during interviews, some members felt guilty about their decision to, in their own words, "return to a secular life," which had meant going back to society after being a renunciate and starting to do things such as eating out or having a relationship. Spatial absence mainly meant the loss of a physical center where they could gather to perform the austerities (shugyō) that had been central to their Aum training. These bodily practices were aimed at awakening energy, attaining psychic powers and, eventually, gaining liberation (Reader 2000). Asahara had guided and monitored followers during training, explaining how to interpret feelings, visions, and bodily reactions and giving orders about what kind of austerities individuals should perform. After 1995, however, the leader was no longer present (he was in prison) and extreme austerities were suddenly interrupted. Members like Hirano no longer experienced the physical pain they had endured during ascetic practices; instead, pain now represented the emotional process of accepting the absence of the leader and of the group they had devoted their life to.

While Aum members moved into absence by moving back into the society they had renounced when they had entered the group, the early Tibetan diaspora's move into absence was a move into exile. The dangerous, often fatal, journeys of Tibetan refugees across the Himalaya imbued the first generation to arrive in exile with a shared set of memories about the traumatic events in the homeland and the subsequent escape. Often, such memories were too 
recent and painful to confront and some members of the elite, struggling to reestablish themselves in exile, actively sought to censor and silence certain accounts (see Shakya 1999: xvii; McGranahan 2005). However, a small number of elite actors, including members of the former aristocracy, government, and religious establishment, began to compose autobiographies dealing with the recent past. Emerging roughly in the first decade of exile, these narratives are already markedly diasporic as works of memory tinged by the present context.

Among these texts is the autobiography Daughter of Tibet, written in English toward the end of the first decade in exile by Rinchen Dolma Taring (1910200o), a Lhasa aristocrat. ${ }^{10}$ After a detailed account of her childhood and two marriages, in which she paints the Tibetan aristocracy in a rosy light, the narrative turns to the events of 1959 and how she was forced to flee Lhasa without her family. The account of her arduous escape into exile, like many of these early texts, uses moments of backward glancing to conceive of home and the left behind homeland as beautiful, pure, and far "above" the rest of the world. As such, it reproduces tropes of a morally pure religious Tibet in isolation that connect to both Tibetan and Western concepts of the hidden "Shangri-la / Shambhala." ${ }^{\prime \prime}$ Such backward glances, written from the perspective of exile, anticipate the growing spatial and temporal distance, as when Taring recounts: "It was a beautiful spring morning, without wind, and still I could see the faraway hills of Lhasa. I was fleeing from the Holy City, yet my mind was haunting it" (1970: 239). Parallel to her emotional relation to home and family, the author reflects on the larger significance of the events of 1959. She ponders the karmic reasons of political events ("they [other nations] made no attempts to help the Tibetans keep Tibet. I suppose this is also karma" [207]), but also frames her own traumatic experience of forced migration in religious terms, musing on whether she should become a Buddhist hermit in India in order to "achieve something spiritual to help Jigme [her husband], my children and all who were suffering as we Tibetans were" (236).

After the escape, Taring did not become a hermit, but instead an active member in the diaspora, serving as director of the educational charity Tibetan Homes Foundation (1962-1975) and engaging in the Tibetan Women's Association (after 1984). In her account of this, she shifted her narrative from her own suffering to the suffering of Tibetans and the absence of those living in

10 Taring received an English school education in Darjeeling, India, in the 1920s. The mere fact that she composed her autobiography in English therefore makes it no less diasporic or authentic, although we can see the influence of her collaborator, the Irish travel writer Dervla Murphy, who was famous for her highly personal and diary-like style of writing.

11 On the concept of the "hidden valley" (bas yul) and "Shangri-la / Shambhala," see Garrett, McDougal, and Samuel 2020. 
Tibet. Thus her life trajectory reflects the shift from personal to collective loss that became central to the early Tibetan diaspora as a feeling community. Seen from the perspective of exile, the homeland had become inaccessibly absent, walled-off by the insurmountable Himalaya and remembered as a past that was lost to those in exile. As the Fourteenth Dalai Lama described in his autobiography first published in 1962, "the vast majority of Tibetans did not escape in time, and now they cannot escape. Behind the Himalayas, Tibet is like a gigantic prison camp." A prison camp, moreover, in which suffering continued every day (Dalai Lama XIV 1997: 190).

These examples show that in situations where communities "move into absence," aesthetic, emotional, and spatiotemporal categories can become entangled with the presence of an absence that is double. Our actors "made sense" of their drastically different positions following events of radical change. They did so by narrating their journeys into absence in spatial and temporal terms and by tying certain aesthetics and attendant emotions to the before and others to the new present. In the process, they created new discursive and conceptual frameworks to express the experience of absence and foster new forms of social belonging. As we will go on to explore in more detail, emotions such as pain and suffering that are usually defined in negative terms were highly productive in these examples. Furthermore, they were related to specific absent places and temporalized in relation to occurrences: the physical pain of asceticism in Aum and the emotional pain of returning to secular life, the suffering during the 1959 uprising and the diaspora's commemoration of continuing suffering in Tibet. In the process, the feeling communities in which these emotions played dominant roles became communities of absence.

\section{Living in Absence}

What are the characteristics of these communities constituted by the presence of an absence? What makes them a community and how can this belonging be sustained? For our actors, absence is present because it is felt, commemorated, and performed; it is both a state that these communities and their individual members find themselves in, and an issue to which they relate. Absence did not bring about these feeling communities in the first place, but it became central in structuring belonging within them through the shared emotions and temporal relations (relations between pasts, presents, futures) that mediated its presence. It is to these codependent aspects in the formation of communities - emotions and time - that we will now turn. 


\subsection{Communities of Absence}

How shared feelings of absence are constructed and structured depends on the specific dynamics of the community and its relationship with the wider sociohistorical context. In the early community of Tibetan refugees in India, for example, commemorative practices emerged as central to its social formation. Such practices, led by the exile administration and influential figures of the diaspora, structured the community's shared emotional grammar in both discourse and practice, with a strong focus on the absent homeland coded into the commemoration of past and present suffering. "Our brothers and sisters," an editorial in the Tibetan-language newspaper Rawang opened on January 13, 1962, "have fallen into tormented circumstances." Tibetans at home, it argued, had become "bound with iron shackles" and were experiencing "suffering beyond imagination or description" (Bhagto Lama 1962). In graphic language, the title of the editorial (similar to many other such texts) called on the exile community to "Look with the Eye of Mercy upon Tibet, Filled with the Blood of Slaughter and the Tears of Suffering." After three years of exile, much had changed. Tibet began to be aesthetically framed as an other to the diaspora, as well as to the diaspora's memory of pre-exilic or pre-1950s Tibet. It was precisely this difference, this relation of absence, that defined the exile community's emotional politics.

While the Tibetan diaspora's emotional politics pivoted on the commemoration of absence, in the case of former Aum members we find the opposite: the social interdiction of relations of memory, and the resulting persistent failure of former members to synchronize with the normative present. Watanabe Eriko joined Aum when she was a teenager. When she left the group in 1999, she found it extremely difficult to reintegrate into a society that was unfamiliar to her. In an interview she said that she had become a renunciate "without knowing anything about society" and so it was "very hard" when she left and she "had to find a new self." She still sees positive aspects of her experience in Aum and is thankful for "the extraordinary experiences, the teachings I received, the possibility to alter my state of consciousness." She still feels different from mainstream society because of her meaningful experience in the organization and its communal life. However, she feels that this experience cannot be explained to "externals" because they will not be able to understand. It is not just that they would fail to recognize it as part of a path to liberation; after the sarin gas attack, Aum's activities and extreme ascetic practices were presented in the public sphere as violent, dangerous, and horrific.

The feelings of Watanabe and others like her do not conform to societal expectations that ex-Aum members will reject their experience and frame it in 
negative terms. As a consequence, they can only share them with other former members. It emerged during interviews and conversations with former members that connections between them had continued after 1995, mainly through informal networks, personal communications and online interactions (for example, by reading former members' blogs and sharing comments on their contents). Through these forms of communication and interaction, although they did not continue practicing together, a community formed around the absence of communal life, of the leader, and of their shared understanding of the path to salvation. This community continues today. In conversations and interviews, former members referred to writing by other members, or to the fact that they could only talk openly about their past experience with people who had shared the same experience. Feelings of connection and belonging in this community are thus not based on kinship, ethnicity, or regional identity, but on the shared experiences of having lived Aum and experienced austerities, and of continuing to feel differently.

As these examples show, emotions emerged as central in our research on these very different communities and how they formed as "communities of absence." Emotions as we understand them are felt by "knowing bodies" already shaped by culture, shared and contested via concepts and discourse, and in turn influence new experience (Pernau and Rajamani 2016: 61). In the contexts of both Tibetan exile and Aum after 1995, emotional concepts and their semantic networks were strongly entangled with Buddhist epistemologies. Absence was felt and articulated through powerful emotions, such as suffering, that derived at least part of their "productivity" from their centrality in religious domains. Such knowledge was important in the conscious and unconscious framing of emotions within larger cosmologies, and in their "right" (moral) performance.

In the case of the Aum community, physical pain during training had a positive valence because it was an indication of the individual's fight with bad karma, which would purify the body and eventually lead to liberation from suffering. Several interviewees explained their ability to overcome fear of death and damnation through their total control over their bodies and their empowerment via ascetic practice. The ability to perform extreme practices was seen as evidence of spiritual achievement, resulting in a higher rank inside the group's hierarchy (Baffelli, forthcoming). Members reaching higher levels also received a holy name (usually that of an important Buddhist figure), bestowed on them directly by the leader himself (Reader 2000: 83). After the sarin gas attack and the arrest of the leader, these practices lost their meaning without the guidance of the guru and the worldview valorizing suffering as the path to 
liberation collapsed. Former members correlated the loss of their connection with the leader with fear, in particular fear of death; some spoke about their fear of falling into hell for severing the bond with Asahara, which Watanabe and some other former members referred to as a bond of love (Baffelli, forthcoming). The entanglement of fear and love made it difficult for them to completely cut their bond with Aum and reject the life they had lived inside it. But in interviews they also used their emotions (pain, love, fear) to explain their difference from other people - only they could understand and share these feelings; "externals" could not know their emotional grammar.

For the early Tibetan diaspora in India, suffering was a key emotional concept in the performance of the feeling community. Suffering mobilized strong Buddhist semantics, particularly so in its discursive deployment by figures such as the Fourteenth Dalai Lama, who in the early decades of the exile community combined both religious and temporal authority in his figure and his "authoritative speech" (Brox 2016: 61-62). A central moment in the community's emotional politics of memory was "1o March Uprising Day," the yearly commemoration of the 1959 uprising in Lhasa. Embedded in sensorially stimulating cultural performances and celebrations (within the community, in settlements, and at the government-in-exile's seat in Dharamsala) as well as in agitated protest (in public venues across and beyond India), speeches given on this day and circulated in the diaspora's public sphere mapped out the feeling community's emotional politics of absence (Nowak 1984: 150-151). In particular, a responsibility of commemoration and political action was derived from the suffering that was located in the past of the uprising and in the present of the oppressed homeland. Reflecting this emotional grammar, the Dalai Lama reminded the diaspora in his 1969 speech that:

The suffering people left in Tibet look up to us. To them we are a symbol of their hopes and aspirations in the fulfilment of the cherished goal of national freedom. It is for this reason that we have been making every effort to fulfil the hopes and trust that have been placed in us by our fellow countrymen in Tibet.... I call upon my countrymen to rededicate themselves to this sacred task.

DIIR 2016: 29-30

Though rich in religious semantics, suffering also connected to the experiences that the refugees shared. In exile, this emotional concept was renegotiated. As the community reassembled, the spatial relations of suffering changed discursively. It now became largely reserved to absent Tibet - to the commemoration 
of the 1959 uprising and to the inaccessible present of an occupied homeland. ${ }^{12}$ Taring had still mused on the central role of suffering on the Buddhist path toward enlightenment, in terms not dissimilar to how former Aum members spoke about pain: "advancement towards enlightenment is gained only through pain, not through pleasure" (Taring 1970: 236). Yet, the Dalai Lama as a political and spiritual authority impressed upon Tibetans in exile the "sacred task" concerning future Tibet, which arose precisely in response to suffering in Tibet. There is a fine but highly significant difference in the way that suffering (sdug bsngal) at home and the situation in exile were formulated across the speeches of the Dalai Lama and other members of the community. While suffering was regularly used to describe the situation in Tibet, exile was far more frequently described using concepts such as hardship ( $d k a^{\prime}$ sdug) and austerity/struggle ( $d k a$ ' spyad 'bad brtson), which relate to suffering by cognates but do not carry the same (religious) semantics. These emotional concepts therefore became central in the diaspora's relation to the absent homeland as an inaccessible space and through the exile Tibetans' (perceived) responsibility for future independence and return. This emotional grammar was not limited to the community's elites, as attested to by its widespread reappearance in editorials (as shown in the case of Rawang above), articles, and speeches. ${ }^{13}$ Even groups defining themselves in political opposition to the government-in-exile, such as the Tibetan Youth Congress, tapped into the same emotional repertoire when they argued for an intensified struggle for independence or reasoned for a Buddhist concession to violent means (TYC 1977).

As this section has illustrated, feelings such as suffering and pain played key social roles in the early Tibetan diaspora and among former Aum members. They were not only mobilized to make sense of a situation; their experience and performance allowed individuals to do belonging through the shared performance of such feelings, whether in events of public commemoration or through informal private networks. Furthermore, they did not stand alone. They functioned in relation to other feelings - hardship and hope, fear and love - which together constituted an emotional grammar at the heart of the creation of community. Shared feelings of belonging were thus coconstituted by shared emotional performances (Schröer 2016).

\footnotetext{
12 The description of this discursive shift provided in this paragraph is based on extended qualitative and lexicometric analyses undertaken in Schröer's PhD dissertation (Schröer 2020). See also Schröer, forthcoming.

For specific examples, see Schröer 2020.
} 
Negative feelings such as suffering or pain can therefore become central to the emotional grammars of communities and to their creation as feeling communities. Their potency derives from both their framing in religious epistemologies and how they connect to individual felt experience in the past. Their mobilization at another point in time (for example, after the 1995 sarin gas attack or during the recurring commemoration of Tibetan National Uprising Day) connects to these layers of meaning and actualizes them under new circumstances, allowing actors to be part of a feeling community in the present. This points to another key dimension of the role of emotions in the creation of communities: time.

\subsection{Temporal Relations}

As we have seen, under certain conditions, absence can powerfully structure emotions central to community formation, but such absence is not only spatial; it also involves complex temporal relations. "Time," Nikolai Ssorin-Chaikov argues, "is not a substance that 'flows' or an area that 'begins' and 'ends.' It is not a thing but a relation between things" (Ssorin-Chaikov 2017: 7). Conceiving of time as a relation not only helps us understand how different temporalities - multiple pasts, presents, and futures - are interrelated, but also how emotions central to the ongoing formation of communities of absence (suffering, pain, fear, hope) are related to these different temporalities. In the two case studies this article draws on, such temporal relations and their emotions are characterized by absence.

The creation of a feeling community of former Aum members, for example, was related to their emotional connection to a specific (past) "Aum time," which was produced by the everyday practices and rhythms of Aum members' daily communal lives. The latter were set by both the slow and painful austerities (long hours sitting in static poses, days and days in confinement and so on) and also by the rapid changes in the organization: members being constantly moved to different centers or new teachings and practices being introduced. In an interview, one member explained her feelings about time in Aum through the metaphor of being on a rollercoaster that moved at a speed three times faster than external society. In 1995 these rhythms were broken by the speed of suddenly changing events (the arrests, the searches, the media feeding frenzy).

Martin Mills argues that the anthropological study of time involves two linked considerations, attention to "temporal ideology" or "why people represent time in a particular way," and to "the embodied practices through which people do time" (Mills 2005: 350). According to his analysis the disarticulation of the two elements becomes evident when "official time is symbolically 
'stopped,' fractured or rendered null and void" (351; italics in original) causing the self to also feel/be fractured. Some members of Aum felt that time had suddenly stopped in 1995 or that it was suspended. Similarly, time may feel fractured for individuals in the diaspora in relation to the time before exile. However, the idea of suspension (Baraitser 2017), absence, or fracture of time is not sufficient to explain how temporal rhythms are changed and/or reshaped after the supposed fracture or interruption of time and how this contributes to the formation of feeling communities.

Time is not absent in the communities we have studied. Rather, time shapes feelings - and the emotional relation to absence - at the root of belonging. Members leaving "Aum time" felt unable to synchronize with an external society that they had often not felt in sync with in the first place and that was now hostile to them. At the same time, some felt disengaged from Aum after it became impossible for them to continue living in a commune without the leader, and to resume the rhythms of their previous life now constantly interrupted by police searches and intrusive media. Some expressed the rupture between Aum time and the present through the forceful image of complete erasure of the past, such as a complete loss of memory of events immediately after the sarin gas attack, as an ex-member describes in her blog:

I still hardly remember the moment just before my memory was erased.... I am still not sure for how many days I lost my memory. But I know that my memory was erased around the time when the subway sarin gas attack happened. This is because I remember that a few days after I lost my memory a large police search started.... It took me more than a month to go back to normal.

Member's blog

The author goes on to explain their memory loss in Buddhist terms; it was not necessarily something negative, but rather a way to cut negative emotions and fear and to get rid of hindrances $($ bonno $)$. Later, they made the decision to leave the organization and to reconstruct their life outside Aum. More than twenty years after they made that decision, they still perceived themselves to be outsiders in mainstream society and, although they managed to find a way to live outside Aum, they still missed the intensity of austerities and their time in Aum. They could not return to Aum time, but the way that they emotionally connected to it - and could only share these feelings among those who had also lived it - were central to the formation of a community of absence among former members. Losing the memory of what happened in 1995 doesn't just 
represent the fracture, shattering, or suspension of time, but the beginning of the presence of absence. The erasure of memory is a strongly emotionalized temporal relation to a specific past, impacting the present.

In the case of the early Tibetan diaspora in India, we find a very different set of temporal relations becoming central to the feeling community. After 1959, Tibetan diasporic identities and nationalism drew as much on ideas of shared Tibetan pasts, both remote and recent, as on the telos of return in the future. Time spent in exile - the diasporic present deeply marked by the simultaneous absent present of the inaccessible homeland - was often framed as preparation. The "sacred task" of the refugees was to struggle for independence, but also to acquire skills and knowledge useful for the future "new Tibet" after return. As the Dalai Lama argued in his Uprising Day speech in 1961:

a heavy responsibility devolves on all of us to prepare ourselves for the day when we can return to our country and build a happier and greater independent Tibet. New Tibet will need thousands of trained and skilled men and women, necessary to bring Tibet in consonance with the spirit of democracy without losing our cultural and religious heritage or our soul.

DIIR 2O16: 2-3

As the quote exemplifies, the concept of return was related as much to the past as to the future. The new/old homeland after return, and its anticipation in the government-in-exile, was conceived of as a democracy. Though this was a first in Tibetan history, policy makers in exile framed democracy as compatible with - even anticipated by - Tibetan tradition and Buddhist teachings. As the 1963 constitution for future Tibet argued, new Tibet would be "a unitary democratic state founded upon the principles laid down by the Lord Buddha" (Dalai Lama XIV 1963: Article 2). As we have seen, the emotional concept of suffering, strongly infused with Buddhist semantics, was temporally related to both the past and the absent present. Here, another set of temporal relations becomes evident within the larger tapestry of the diasporic feeling community, equally infused with religious semantics. Reaching back into the golden age of the Tibetan empire's Buddhist rulers in the 7 th to 9 th centuries - and further to the life of the historical Buddha more than one and a half millennia earlier - the teachings of the Buddha were brought into dialogue with the modern concept of democracy encountered in postcolonial India and projected into the hopeful Tibetan future. In an exchange of legitimacy, democracy confirmed the Buddhist teachings, which in turn had long anticipated it. This allowed Tibetans in exile to simultaneously safeguard their faith and 
cultural heritage while embracing the new as strategic knowledge for a future independent Tibet, sanctioned by the moral license afforded through its compatibility with Buddhism.

As the examples we have given show, ways of relating present experience to pasts and futures (i.e., "temporal relations") are encoded into the emotions central to the creation of belonging in the communities we study. Instead of operating on the totalizing level of impersonal "regimes of historicity" (Hartog 2015) or "temporal regimes" (Jordheim 2014) that seek to describe the entirety of "a society's relations to time" (Hartog 2015: 1), we have focused here on the highly personal relations that constitute the very threads with which the fabrics of communities are woven. By unearthing complex temporal relations connecting multiple times, such as the heroic past of the Tibetan empire and the future of the Tibetan people, our intention is not to discount the importance of temporalized emotions with less complex temporal relations. Certainly, Tibetan refugees often felt nostalgic or melancholic about the bygone past, and these feelings did not necessarily always relate to the present, let alone the future. Even then, however, emotions such as nostalgia did not stand alone; they were constituent elements in an emotional repertoire, the grammar of which often included complex temporal interconnections. Like emotion, we take time as a learned and intersubjective aspect of experience and meaningmaking specific to social groups and their emergence. ${ }^{14}$ Just as the emotions at the heart of the creation of a feeling community, such as suffering, pain, or hope, are social in nature, so too are temporal relations learned, shared, performed, and contested intersubjectively, belonging to specific communities under specific circumstances, at specific moments in time.

Is time felt? Is temporality a feeling (Clark 2019: 6)? Scholarship on specific temporal emotions like nostalgia, including the seminal works by Peter Fritzsche (2001, 2004) and Svetlana Boym (2001), have conceived of them as individual or collective emotional dispositions toward not only objects, events, and people, but also specific times or periods. Similarly, Lisa Baraitser (2017) has explored a whole range of feelings relating to time, for example feelings of time not passing at all, passing too slowly, recurring, and so on. Such emotional relations to time are one important dimension of meaning-making. However, if we understand time itself as relational in the creation of belonging, then we also need to analyze the temporalization of emotions. This means that emotions such as hope, longing, loss, fear, grief, or regret are at the heart of the

14 On social time, see Adam 1995. On time as a symbolic process, see Munn 1992. For anthropological works on how time is represented, lived, understood, embodied, and marked, see: Gell 1992; James and Mills 2005; Hodges 2008. 
temporal relations in our actors' experience. As part and parcel of complex and highly specific temporal matrices, they are fundamental to the creation, maintaining, and ending of belonging. They are not just used by actors as ways to relate to, for example, a singular "past." Both discursively and in practice, Tibetan refugees and former Aum members used these feelings to relate between different times - for example, between Aum time and its absent presence in the present or between radically different presents, such as those of the Tibetan diaspora and of Tibetans inside Tibet.

Over the years, former Aum members continued their balancing act between finding ways to compromise with a secular life and maintaining contacts with other members who shared the same experience and could fully appreciate, in the words of Watanabe, what a "special space" Aum had been. Their belonging to this feeling community is based on the condition that this space - Aum as they had lived it - does not exist anymore. The absence they felt was a permanent absence of physical inaccessibility and temporal irreversibility, which culminated in July 2018 with the executions of Asahara and twelve other Aum members. While these executions were seen by some commentators as the appropriate way to conclude a painful chapter of Japanese history (Baffelli and Reader 2018), some former Aum members had to come to terms with the death of their leader and friends. Moreover, they could not publicly express their loss, grief, and pain. In a long emotional post on a blog titled "Goodbye, dharma friends" a former member recalls the shocking moment when they learned about the executions; they remember the long years their friends spent in prison and the life they had missed out on. Members of the Aum feeling community are aware that their feelings toward their fellow members and toward the, now irreversible, absence that they live with, will not and cannot be accepted in mainstream society. Since the Aum feeling community cannot reconstruct itself in a way that would be acceptable to that society, its present time continues to be characterized by the members' pain - the pain of having returned to secular life and of having cut their bond with their leader.

An intense and highly emotional relationship between the present(s), suffering, and absence was also central to early Tibetan diasporic discourse, although differing markedly from the experience of former Aum members. As exile stretched from months to years, the diaspora worked hard toward economic self-sufficiency, striving to ameliorate the condition of displacement through processes of emplacement (Diehl 2002: 7). Thus, the Tibetan community in exile restructured itself according to the context of diaspora, coping with new hardships, and carefully incorporating elements of democratic governance and modern education. The community's emotional pivot, however, remained in the homeland. Though Tibet had become, in the words of the 
Dalai Lama quoted above, inaccessible like a "prison camp" hidden behind the Himalaya, the emergent diasporic public sphere kept up a constant stream of "News from Tibet," in both Tibetan and English. These news reports provided inventories of conditions and events in Tibet shrouded in obscurity behind the "bamboo curtain" of the People's Republic of China in the 196os and 197os, and offered highly personal and emotional descriptions of the suffering and destruction otherwise largely unreported in international media (Samphel 2003). Two present times therefore discursively emerged, both of which were described as "today," "nowadays," or "recently." One was located in the homeland, characterized by suffering and felt through its absence, and the other in exile, characterized by hardship, rehabilitation, and the struggle for independence. While the diasporic present could be a "new time" in which Tibetan refugees could participate in global material and scientific advances, time in the homeland seemed to stagnate with no way out of the present of oppression and suffering. In the eyes of the diasporic administration, only Tibetans in exile could find a way into a better future.

\section{Moving Out of Absence (Or Not)}

Returning to the metaphor of movement, a final point to be considered is the possibility for these communities to move out of absence. What would happen if the defining element of their existence as communities ceased to be? Is it even possible for these communities to move out of absence at some point and reshape themselves in different terms?

Both the Tibetan diaspora and former Aum members have continued to live in absence for decades. In both cases, there has been a constant negotiation between belonging and nonbelonging, between feeling in sync and out of sync. ${ }^{15}$ Former Aum members, for example, have been able to partially negotiate their belonging to mainstream society and sync in when they have needed to find a job, receive medical treatment, or interact with their families. However, they have also constantly felt out of sync with the outside world and mainly socialized with other former members who understand their feelings and their language. Ueda characterized Aum members as "soft terrorists" who said "no" to society: they did not have a career, they did not get married, and they did not have children. For many of them, she said, "it is difficult to move the time," because they are still stuck in "Aum time." The present time for former members is characterized by the impossibility of turning back the clock to

15 For a theoretical discussion on out-of-syncness, see Jordheim, forthcoming. 
Aum time and living together again in the Aum community. The irreversibility of the violent acts perpetrated by Aum members and of the executions also preclude the possibility of conceiving of a future, making it even more difficult for them to find an "ending point." Their only remote hope is connected to Buddhist teachings and temporalities, since it lies in the future possibilities afforded by reincarnation. "If I was to reincarnate and meet the guru," a former member said, "I would do it all again."

For the Tibetan diaspora, moving out of the absence of the homeland through return to new/old Tibet has remained the quintessential "sacred task" in exile. The concept of return was and remains, as explained above, fundamentally transtemporal (Vásquez 2008: 162), relating to both the past and the future. Hope and conviction have been central to the diaspora's emotional repertoire temporalized through the concept of return. Yet, as much as the diasporic identity pivots on the hope for return, the diasporic community has lived in the absence of the homeland for over six decades. While gradual shifts in Chinese policy after the late 1970s have allowed a number of Tibetans to return to Tibet, many more have either not been able or willing to return under current conditions. New communication technologies offer some ways of mitigating the spatial divide, but as recent events have shown, these technologies easily fall prey to state intervention, and their use can actively endanger those in the homeland. The dilemma of a diaspora lies in the permanence of its structures. The better that rehabilitation in exile went over the years, the greater the danger was of putting down "roots" in another country. The decision of some members to forego refugee status in favor of a foreign passport, or events such as to "mix" with other populations and thus lose a "purity" coded in cultural, linguistic, and racial terms (Lokyitsang 2018), loom as dangers to the community. Therein lies the importance of the presence of absence, discursively stabilized through the commemoration of temporalized "negative" emotions, designed to rouse hope and conviction for future change.

What the two examples from our research show here is that while absence may play a vital role in community formation, moving "out" of such absence can be difficult for reasons both external and internal to the communities. For former members of Aum, there has been no way back to the time and the community as it had been before the events of 1995. At the same time, there has been no way out of Aum's legacy, leaving many former members feeling out of sync with mainstream society. In the case of the Tibetan diaspora, especially in the early decades but in many ways continuing until today, the absent homeland has been integral to diasporic identity. Holding on to this keeps the hope for return alive but comes at the cost of potential alienation in exile, where 
many Tibetan refugees have consciously refused to put down roots stronger than their emotional ties to absent Tibet.

\section{Conclusion}

In this article we have argued that belonging can be characterized by absence. In particular we have shown that this absence is double - both spatial and temporal. The feeling communities of absence we have discussed are produced by emotions such as suffering and pain that are felt and performed by our actors. As our case studies have revealed, such shared feelings are vitally productive in the forming and maintaining of belonging. Furthermore, we have demonstrated how these emotions are embedded in specific temporal relations, which reveal how the presence of absence is coproduced by temporal and emotional relations to pasts, presents, and futures. Understanding aesthetics/aisthesis as a broader domain of sense perception therefore means including the experience of time in the analysis of the aesthetics of belonging.

In the examples taken from our work on the Tibetan diaspora and former members of Aum, emotions, in particular suffering, have been impacted by Buddhist epistemologies and notions of time, such as ideas of karma and reincarnation. Religious semantics have thereby informed, through emotions, how our actors have made sense of their experiences of absence and created new forms of community. However, concerns about absence - about "what is not anymore," and "what is not yet" (Searle 2020: 167; emphasis in original) are not limited to religious contexts. The communities we have discussed are far from the only ones to have established complex temporal relations between multiple times, or to have found themselves facing the presence of absence. ${ }^{16}$ Therefore, we suggest that understanding these entanglements of time and emotions may produce new and important insights into community formation in other contexts.

16 For example, in other writings (Baffelli and Schröer 2020) we have reflected on how, during the Covid-19 pandemic, we found ourselves in a condition of (double) absence that created new mediated practices of intimacy. 


\section{Acknowledgments}

This article benefited greatly from discussions, comments, and criticisms from the members of the research group "The Aesthetics of Religious Belonging." We are also thankful to Helge Jordheim and Margrit Pernau for reading and commenting on drafts, and to the anonymous reviewers and Numen editors for their comments and criticisms. Fieldwork in Japan was supported by the Japan Foundation Endowment Committee, The Great Britain Sasakawa Foundation, and Ochanomizu University Institute for Gender Studies.

\section{References}

Abdelmalek, Sayad. 1999. La double absence: des illusions de l'émigré aux souffrances de l'immigré. Paris: Le Seuil.

Adam, Barbara. 1995. Timewatch: The Social Analysis of Time. Cambridge: Polity Press. Baffelli, Erica. 2018. "Aum Shinrikyō." In Lukas Pokorny and Franz Winter (eds.), Handbook of East Asian New Religious Movements, Leiden: Brill, 193-210.

Baffelli, Erica. 2020. "Did Aum Shinrikyō Really End?” In Michael Stausberg, Carole Cusack, and Stuart A. Wright (eds.), Religious Demise: How Religions Die, Decline, or Dissipate, London: Bloomsbury, 49-66.

Baffelli, Erica. Forthcoming. "Living Aum: Austerities, Emotion, and the Feeling Community of Former Aum Members." Nova Religio 25(3).

Baffelli, Erica, and Ian Reader. 2018. "The Aum Shinrikyō Executions: Why Now?" Fair Observer. 13 July. URL: https://www.fairobserver.com/region/asia_pacific/aum -shinrikyo-asahara-shoko-execution-tokyo-subway-attack-japan-news-71111/ (accessed April 20, 2021).

Baffelli, Erica, and Frederik Schröer. 2020. "Spatio-Temporal Translations: Practices of Intimacy under Absence." Anthropology in Action 28(1): 57-62. DoI:10.3167/ aia.2021.280111.

Baffelli, Erica, Jane Caple, Levi McLaughlin, and Frederik Schröer. 2021. "The Aesthetics and Emotions of Religious Belonging: Examples from the Buddhist World." Numen 68(5-6): 421-435. DOI:10.1163/15685276-12341634.

Baraitser, Lisa. 2017. Enduring Time. London: Bloomsbury Academic.

Bhagto Lama. 1962. "gLeng brjod: dmar bsad kyi khrag dang, sdug bsngal gyi mig chus khengs pa'i Bod ljongs la brtse ba'i spyan gyis gzigs dang” [Editorial: Look with the Eye of Mercy upon Tibet, Filled with the Blood of Slaughter and the Tears of Suffering]. Rang dbang gar shog: Freedom 2(45): 2 .

Boddice, Rob. 2019. A History of Feelings. London: Reaktion Books. 
Boym, Svetlana. 2001. The Future of Nostalgia. New York: Basic Books.

Brox, Trine. 2016. Tibetan Democracy: Governance, Leadership and Conflict in Exile. London: I. B. Tauris.

Buswell, Robert E., Jr., and Donald S. Lopez Jr. 2014. The Princeton Dictionary of Buddhism. Princeton, NJ: Princeton University Press.

Cho, Lily. 2007. "The Turn to Diaspora." TOPIA: Canadian Journal of Cultural Studies 17: 11-30. DOI:10.3138/topia.17.11.

Clark, Christopher. 2019. Time and Power: Visions of History in German Politics, From the Thirty Years' War to the Third Reich. Princeton, NJ: Princeton University Press.

Dalai Lama XIV. 1963. Bod kyi rtsa khrims: Constitution of Tibet. New Delhi: Bureau of His Holiness the Dalai Lama.

Dalai Lama XIV. 1984. "The Statement of His Holiness the Dalai Lama on the Occasion of the 25th Anniversary of the Tibetan National Uprising Day, 10 March 1984." In Information Office (ed.), Tibet - 84: 25 Years of Struggle and Reconstruction, Dharamsala: Organizing Committee, Information Office, Central Tibetan Secretariat, $\mathrm{np}$.

Dalai Lama XIV. 1997. My Land and My People: The Original Autobiography of His Holiness the Dalai Lama of Tibet. New York: Grand Central.

Diehl, Keila. 2002. Echoes from Dharamsala: Music in the Life of a Tibetan Refugee Community. Berkeley: University of California Press.

DIIR (Department of Information and International Relations, Central Tibetan Administration) (ed.). 2016. Tibet and the Tibetan People's Struggle: 10 March Statements of His Holiness the Dalai Lama (1961-2011). Dharamsala: DII R CTSA.

Fritzsche, Peter. 2001. "Specters of History: On Nostalgia, Exile, and Modernity." The American Historical Review 106(5): 1587-1618. DoI:10.2307/2692740.

Fritzsche, Peter. 2004. Stranded in the Present: Modern Time and the Melancholy of History. Cambridge, MA: Harvard University Press.

Gammerl, Benno, Jan Simon Hutta, and Monique Scheer. 2017. "Feeling Differently: Approaches and Their Politics." Emotion, Space and Society 25: 87-94. DOI:10.1016/j. emospa.2017.07.007.

Garrett, Frances, Elizabeth McDougal, and Geoffrey Samuel (eds). 2020. Hidden Lands in Himalayan Myth and History: Transformations of sbas yul through Time. Leiden: Brill.

Gell, Alfred. 1992. The Anthropology of Time: Cultural Constructions of Temporal Maps and Images. Oxford: Berg.

Grieser, Alexandra K., and Jay Johnston (eds.). 2017. Aesthetics of Religion: A Connective Concept. Berlin: De Gruyter.

Hartog, François. 2015. Regimes of Historicity: Presentism and Experiences of Time. Saskia Brown (trans.). New York: Columbia University Press. 
Harvey, Peter. 2013. "Dukkha, Non-Self, and the Teaching on the Four 'Noble Truths." In Steven M. Emmanuel (ed.), A Companion to Buddhist Philosophy, Malden, MA: Wiley-Blackwell, 26-45.

Hodges, Matt. 2008. "Rethinking Time's Arrow: Bergson, Deleuze and the Anthropology of Time." Anthropological Theory 8(4): 399-429. DoI:10.1177/14634996o8o96646.

Information Office of His Holiness the Dalai Lama. 1981. Tibetans in Exile: 1959-1980. Dharamsala: Information Office, Central Tibetan Secretariat.

Inoue Nobutaka and Shūkyō jōhō risāchi sentā (eds.). 2011 Jōhō jidai no Ōmu Shinrikyō [Aum Shinrikyō in the Information Age]. Tokyo: Shunjūsha.

Inoue Nobutaka and Shūkyō jōhō risāchi sentā (eds.). 2015. Ōmu Shinrikyō o kenshō suru [Examining Aum Shinrikyō]. Tokyo: Shunjūsha.

James, Wendy, and David Mills (eds.). 2005. The Qualities of Time: Anthropological Approaches. London: Bloomsbury.

Johannsen, Dirk, Anja Kirsch, and Jens Kreinath (eds.). 2020. Narrative Cultures and the Aesthetics of Religion. Leiden: Brill.

Jordheim, Helge. 2014. "Introduction: Multiple Times and the Work of Synchronization." History and Theory 53(4): 498-518. DoI:10.1111/hith.10728.

Jordheim, Helge. Forthcoming. "In Sync/Out of Sync." In Zoltán Simon and Lars Deile (eds.), Historical Understanding Today, London: Bloomsbury.

Lokyitsang, Dawa T. 2018. "Who is a Pure Tibetan?: Identity, Intergenerational History, and Trauma in Exile." In Shelly Bhoil and Enrique Galvan-Alvarez (eds.), Tibetan Subjectivities on the Global Stage: Negotiating Dispossession, Lanham, MD:Lexington Books, $195^{-211 .}$

Maekawa Michiko. 2001. "When Prophecy Fails: The Response of Aum Members to the Crisis." In Robert J. Kisala and Mark R. Mullins (eds.), Religion and Social Crisis in Japan: Understanding Japanese Society through the Aum Affair, New York: Palgrave, 179-210.

McGranahan, Carole. 2005. "Truth, Fear, and Lies: Exile Politics and Arrested Histories of the Tibetan Resistance." Cultural Anthropology 20(4): 570-600. Dor:10.1525/ can.2005.20.4.570.

McGranahan, Carole. 2018. "Refusal as Political Practice: Citizenship, Sovereignty, and Tibetan Refugee Status." American Ethnologist 45(3): 367-379. Dor:10.1111/ amet.12671.

Methfessel, Thomas. 1997. "Socioeconomic Adaptation of Tibetan Refugees in South Asia over 35 Years in Exile." In Frank J. Korom (ed.), Tibetan Culture in the Diaspora: Papers Presented at a Panel of the 7 th Seminar of the International Association for Tibetan Studies, Graz 1995, Vienna: Austrian Academy of Sciences, 13-24.

Meyer, Birgit (ed.). 20o9. Aesthetic Formations: Media, Religion, and the Senses. New York: Palgrave Macmillan. 
Mills, Martin A. 2005. "Living in Time's Shadow: Pollution, Purification and Fractured Temporalities in Buddhist Ladakh." In Wendy James and Martin A. Mills (eds.), The Qualities of Time: Anthropological Approaches, London: Bloomsbury, 349-366.

Munn, Nancy D. 1992. "The Cultural Anthropology of Time: A Critical Essay." Annual Review of Anthropology 21: 93-123. D OI:10.1146/annurev.an.21.100192.000521.

Nowak, Margaret. 1984. Tibetan Refugees: Youth and the New Generation of Meaning. New Brunswick, NJ: Rutgers University Press.

Pernau, Margrit. 2017. "Feeling Communities: Introduction." The Indian Economic \& Social History Review 54(1): 1-20. DOI:10.1177/oo19464616683477.

Pernau, Margrit, and Imke Rajamani. 2016. "Emotional Translations: Conceptual History beyond Language." History and Theory 55:46-65. DoI:10.1111/hith.10787.

Poser, Anita von, Edda Hayken, Thi Minh Tam Ta, and Eric Hahn. 2019. "Emotion Repertoires." In Jan Slaby and Christian von Scheve (eds.), Affective Societies: Key Concepts, London: Routledge, 241-251.

Reader, Ian. 200o. Religious Violence in Contemporary Japan: The Case of Aum Shinrikyō. Honolulu: University of Hawai'i Press.

Reddy, William M. 2001. The Navigation of Feeling: A Framework for the History of Emotions. Cambridge: Cambridge University Press.

Rosenwein, Barbara H. 2006. Emotional Communities in the Early Middle Ages. Ithaca, NY: Cornell University Press.

Safran, William. 1991. "Diasporas in Modern Societies: Myths of Homeland and Return." Diaspora 1(1): 83-99. DoI:10.1353/dsp.1991.0004.

Samphel, Thubten. 2003. "Virtual Tibet: The Media." In Dagmar Bernstorff and Hubertus von Welck (eds.), Exile as Challenge: The Tibetan Diaspora, Hyderabad: Orient Longman, $167-85$.

Schröer, Frederik. 2016. “Of Testimonios and Feeling Communities: Totaram Sanadhya's Account of Indenture." Südasien-Chronik - South Asia-Chronicle 6: 149-174. DOI:10.18452/8519.

Schröer, Frederik. 2020. "Reassembling the Feeling Community: Space, Time, and Morality in the Tibetan Diaspora in India, c. 1959-1979." PhD dissertation, Freie Universität Berlin.

Schröer, Frederik. Forthcoming. "Resistance and Suffering: Shared Emotions in the Early Tibetan Diaspora in India." Copenhagen Journal of Asian Studies.

Searle, Adam. 2020. "Absence." Environmental Humanities 12(1): 167-172. Dor:10.1215/ 22011919-8142253.

Shakya, Tsering. 1999. The Dragon in the Land of Snows: A History of Modern Tibet since 1947. London: Pimlico.

Shimazono, Susumu. 1997. Gendai shūkyō no kanōsei: Ōmu Shinrikyō to bōryoku [Possibilities of Contemporary Religions: Aum Shinrikyō and Violence]. Tokyo: Iwanami Shoten. 
Ssorin-Chaikov, Nikolai. 2017. Two Lenins: A Brief Anthropology of Time. Chicago: Hau Books.

Taring, Rinchen Dolma. 1970. Daughter of Tibet. London: John Murray.

Tölölyan, Khachig. 2007. "The Contemporary Discourse of Diaspora Studies." Comparative Studies of South Asia, Africa and the Middle East 27(3): 647-655. DOI:10.1215/1089201x-2007-040.

Townsend, Dominique. 2021. "Feeling the Way to Revelation: Patterns of Doubt and Persuasion in Tibetan Buddhist Autobiographical Treasure Narratives." Numen 68(5-6):513-539. DoI:10.1163/15685276-12341638.

TYC (Tibetan Youth Congress). 1977. "Editorial: The 4th Working Committee Meeting and the Meaning of Freedom." Rangzen 2(1): 1-3.

Vásquez, Manuel A. 2008. "Studying Religion in Motion: A Networks Approach." Method and Theory in the Study of Religion 20: 151-184. DOI:10.1163/157006808X283570.

Williams-Oerberg, Elizabeth. 2021. "Buddhist Ritual as 'Connectionwork': Aesthetics and Technologies of Mediating Religious Belonging." Numen 68(5-6): 488-512. DOI:10.1163/15685276-12341637. 